\title{
Forestry and Wildlife in Morocco
}

\section{S. P. Mills}

Morocco still has wild areas and wildlife to save. But conservation is linked with forestry and where there is conflict forestry takes priority, says the author, who spent six months there in 1975 on a WWF commission. Destruction of birds as well as their habitat was widespread. The need for outside help to provide conservation education particularly in the forest service is urgent.

The Moroccan authorities have taken two important preliminary conservation steps. Helped by French scientists at Rabat University, they have drawn up a list of protected birds and mammals, and distributed posters illustrating these to forest stations throughout the country. At the same time the forestry department has been given sole responsibility for wildlife; the man in charge is an engineer with an office where the relevant papers and information are stored. These steps, taken in response to a visit by the World Wildlife Fund's President a few years ago, effectively disarm superficial criticism, but since then the outside world has paid little attention to Morocco's threatened fauna, and conservation has made almost no further progress.

Like most commercially orientated government forestry departments Morocco's 'Eaux et Forêts' has discovered the advantages of the quick return on fast-growing pines, and is investing furiously in vast sterile plantations, creating an increasingly acidic soil. On the one hand conservation has been recognised as a priority, and on the other economics has kept it at the bottom of the list. Practice too shows a lack of understanding. The once richly endowed Forêt Diplomatique near Tangier was cleared of its undergrowth in the middle of spring, regardless of the many nesting birds, because it was 'unsightly for tourists', and in other areas we found scrub being cleared, which could easily have been delayed a month, without thought for breeding Dartford warblers Sylvia undata and short-toed eagles Circaëtus gallicus.

The rural people continue to maraud, illegally but unchecked, in the deciduous forests, stripping the trees for firewood, building material and fuel for charcoal burning. The result is hundreds of miles of stunted scrub. A few species like the Sardinian warbler Sylvia melanocephala have benefited, and short-toed eagles have made a gallant attempt to adapt, becoming ground nesters in some areas, but most species have disappeared. The contrast between the destroyed forests and the little pockets of pristine highland deciduous woods bristling with woodpeckers, songbirds and flowers, was eloquent.

Among a poor population like Morocco's it is understandable to find little or no respect for nature. Birds are trapped and shot indiscriminately, and nests, particularly conspicuous and interesting raptor nests, destroyed with crushing regularity by a ubiquitous people with leisure to find them. Our raptor survey showed a disturbing paucity of immatures, and many of the adults we saw may be of the same generation, and thus likely to die off within a short time of each other, leaving very few replacements. Some species, therefore, may be much closer to extinction than present numbers imply. Black-winged kites Elanus caeruleus for instance, about which we have 
heard some encouraging predictions, are usually robbed and are having very little breeding success.

Birds are still the subject of primitive superstitions. It is, ironically, quite common practice to seek increased intelligence by eating the heart of a hoopoe Upupa epops, and we only found them breeding in the remotest hills and mountain ranges. Other brightly coloured species like the bee-eater Merops apiaster and the roller Coracias garrulus suffer similar persecution, and we were alarmed to find the heads of green woodpeckers Picus levaillanti nailed as good-luck trophies to the walls of foresters' homes.

In the meantime, wildlife in Morocco experiences the inevitable disadvantages of human progress. The great marshes of the west coast have been drained to irrigate the country's richest agricultural belt. The crested coot Fulica cristata, purple heron Ardea purpurea, marbled duck Anas angustirostris and white-headed duck Oxyura leucocephala have either disappeared or withdrawn to the residual lakes and pools which, like the famous Merdja Zerga, are also continually threatened. The rush to cultivate the wilderness of the Rif mountains has produced the usual massive overgrazing and unterraced cultivation, with vast areas losing their top soil. It was perhaps no coincidence that we recorded the Rif's first desert white wagtail Motacilla alba subpersonata. At the same time the more modern farming co-operatives in the south of the range bring with them the scourge of pesticides.

Yet, despite all this Morocco is not so far from a satisfactory conservation situation. Some forests have survived, and even pine forests save the soil from the wind and provide cover for wildlife - most of what we saw was in or near forest 'preserves'. A network of officers is established throughout the country, but without an expert in wildlife conservation at the centre and a system for training the officers in the field little can be achieved. It is for this that WWF and other bodies should be giving time and money.

Morocco is still politically sensitive, having only been independent of the French for twenty years. Although conservation officers who are not tied to the economic focus of forestry are essential, the impetus, if not the initiative, must be Moroccan. And Western Europeans have to admit that our conservation expertise has been gained at the expense of our wildlife. Morocco still has wild areas to save.

\section{Acknowledgment}

The author wishes to thank the Carl Zeiss Company, London, for the provision of excellent binoculars for the expedition.

\section{References}

1. DE BALSAC, H. and MAYAUD, N. 1962. Les Oiseaux du Nord-Ouest de l'Afrique. Lechevalier, Paris.

2. BANNERMAN, D. and J. 1952 An ornithological journey in Morocco in 1951. Ibis 94, 406-433.

3. BROSSET, A. 1961. Ecologie des oiseaux du Maroc oriental, Travaux de l'Institut Scientifique Cherifien. Série Zoologie 22, 1-155.

4. ETCHECOPAR, R.D. and HUE, F. 1967. Birds of North Africa. Edinburgh.

5. HARTERT, E. and JOURDAIN, K. 1923. The hitherto known birds of Morocco. Novitates Zoologicae 30, 91-152. 
6. LATHBURY, G. 1970. Review of the birds of Gibraltar. Ibis 112, 25-43.

7. LYNES, H. 1924. An ornithological visit to north-west Morocco. Novitates Zoologicae 31, 49-103.

8. MEADE-WALDO, E.G.B. 1903. Bird notes from Morocco and the Great Atlas. Ibis 3, 196-214.

9. PINEAU, J. and GIRAUD-AUDINE, M. 1974, 1975. Notes sur les migrations traversant l'extrême nord-ouest du Maroc. Alauda 42, 159-188. Nidification du busard des roseaux en milieu non aquatique dans la région de Tanger. Ibid. 281-288. Notes complémentaires sur les migrations traversant l'extrëme nord-ouest du Maroc. Alauda 43, 135-141.

10. SAGE, B.L. and MEADOWS, B.S. 1965. Some recent ornithological observations in Morocco. Bulletin de la Société des Sciences Naturelles et Physiques du Maroc 45, 191-233.

11. SMITH, K.D. 1965. On the birds of Morocco. Ibis 107, 493-526.

12. VALVERDE, J.A. 1955. Aves de Marriecos Español en Julio. Ardeola 2, 87-114.

13. VERNON, J.D.R. 1973. Observations sur quelques oiseaux nicheurs du Maroc. Alauda 41, 101-109.

The author with Anthony Strubell was commissioned by WWF to study the raptors in northern Morocco and report on conservation there. They spent the first six months of 1975 there. The author received a Churchill Fellowship for the work.

Stephen P. Mills, Suntrap, Forest Hill, Oxford.

\section{Trust to Breed Indian Crocodiles}

The Madras Crocodile Bank Trust has been created by the Madras Snake Park Trust, aided by a substantial grant from the World Wildlife Fund, to breed and rear crocodiles for release in the wild. Young crocodiles will be offered to state governments for re-stocking wild habitat, provided the governments guarantee to protect them. All three of India's crocodile species are highly endangered - the Trust describes the gharial Gavialis gangeticus as "the most endangered crocodilian in the world' - and points out that the most urgent need if they are to be saved is effective protection of suitable wild habitat, which rests with the state forest departments. The Trust, whose director is Romulus Whitaker, also has plans for education and research.

\section{Thames Triumph}

Ninety-one species of fish have now been recorded in the Thames in the $40 \mathrm{~km}$ from central London down to Tilbury where 15 years ago pollution from sewage and industrial effluents was so severe that all fish life had been killed except for a few eels. Two large modern sewage-treatment works built since then and other smaller projects have transformed the river, and the fish have seized the opportunity. So have the birds, as a book reviewed by Richard Fitter in this issue describes. Among the fish recorded was a sea-horse - the first record for the Thames - and shrimps are abundant.

\section{Blackbuck Increase}

The small herd of blackbuck released in the Bandhavghar National Park, in northern India, has doubled in numbers, reports Anne Wright, one of our FPS Consultants in India. The original animals were released in 1971 with the help of an Oryx $100 \%$ Fund grant - see Oryx, January 1972, page 228 . The blackbuck are enclosed in the area of the ancient Bandhavghar Fort inside the park; well protected from tigers, although a tigress managed to get in recently - no-one knows how - and killed one blackbuck. The park is 105 square $\mathrm{km}$ and harbours 13 tigers, a high average of one to every three square miles, as well as gaur, four species of deer, blue bull, chinkara, sloth bear and panther, among others. 